\title{
СОВРЕМЕННЫЕ АСПЕКТЫ УЧЕТА И АНАЛИЗА ЗАПАСОВ
}

\section{Татаровский Юрий Алексеевич}

к.э.н., доцент, доцент

ФГАОУ ВО «Самарский государственный экономический университет»

Меликян Айкуи Агасовна

студент

Аннотация: В статье раскрыта значимость построения эффективной системы учета материально-производственных запасов, приведены учетные записи в части операций, отражающих движение запасов в торговых организациях. Авторами представлены критерии признания политики управления запасами эффективной. Актуализирована задача анализа обесценения запасов и динамики резерва по их обесценению с точки зрения оценки эффективности управления запасами.

Ключевые слова: запасы, учет запасов, анализ запасов, управление запасами, оборачиваемость запасов, торговые предприятия.

\section{MODERN ASPECTS OF INVENTORY ACCOUNTING AND ANALYSIS}

\section{Tatarovsky Yury Alekseevich Melikyan Aikui Agasovna}

\begin{abstract}
The importance of building an effective inventory accounting system and accounting records in terms of operations reflecting the inventory movement $\mathrm{n}$ trade organizations are considered in the article. The criteria for recognizing an effective inventory management policy are suggested by aurthors. The task of analyzing the inventory impairment and the dynamics of the reserve for their impairment from the point of view of assessing the inventory management effectiveness is updated.

Key words: inventory, inventory accounting, inventory analysis, inventory management, inventory turnover, trading enterprises.
\end{abstract}




\section{ВСЕРОССИЙСКИЕ НАУЧНЫЕ ЧТЕНИЯ

Качество собранной информации влияет на управленческие решения, а значит, на эффективность и результативность финансово-хозяйственной деятельности предприятия, следовательно, каждая организация должна его обеспечить в полном объеме [1, с. 128]. Деятельность организации необходимо начать именно с правильной организации учетного процесса. Управленческий состав организации в первую очередь должен установить, какие именно виды учета нужны для конкретной организации и как наилучшим образом совместить виды учета и др. Тем самым важно понять, какое ведение учета запасов будет наиболее целесообразным и рациональным для данной организации.

Каждому предприятию для того, чтобы избежать лишних незапланированных трат, а в дальнейшем убытков, особенно если материалы закупаются на заемные денежные средства, необходимо создать оптимальный объем материально-производственных запасов и в дальнейшем эффективно управлять данными запасами. Данный аспект является одним из важных условий получения высокой финансовой отдачи от торговой деятельности компании и повышения ее эффективности. Увеличить продажи и минимизировать общие затраты на создание и хранение запасов - это цель по управлению запасами любого предприятия и, в частности, торгового [2, с. 46].

Материалы являются неотъемлемой частью производственной деятельности каждого экономического субъекта. Эти инструменты торговли необходимы для перепродажи, предоставления услуг, для производства продуктов, для выполнения работы. Свойства материалов полностью используются во всех циклах, участвуя в производстве, передавая свою ценность вновь создаваемому продукту.

Проводки по поступлению и выбытию материальных запасов на примере предприятия, занимающегося покупкой и перепродажей товара:

1) Дт 41 «Товары» Кт 60 «Расчеты с поставщиками и подрядчиками» отражено поступление товаров на сумму фактической себестоимости их приобретения.

2) Дт 19 «НДС по приобретенным ценностям» КТ 60 «Расчеты с поставщиками и подрядчиками» - на сумму НДС.

3) Дт 41 «Товары» Кт 76 «Расчеты с разными дебиторами и кредиторами» - учтены расходы на транспортировку товаров.

4) Дт 62 «Расчеты с покупателями и заказчиками» Кт 90.01 «Выручка» отражена реализация товаров покупателям. 


\section{ВСЕРОССИЙСКИЕ НАУЧНЫЕ ЧТЕНИЯ

5) Дт 90.02 «Себестоимость продаж» Кт 41 «Товары» - списана себестоимость проданных товаров (по методу списания утвержденному для предприятия учетной политикой) плюс транспортные расходы.

6) Дт 90.03 «Налог на добавленную стоимость» Кт 68.02 «Налог на добавленную стоимость».

Каждому предприятию для обеспечения бесперебойного и эффективного производственного процесса необходимо настроить качественный учетноаналитический для того, чтобы руководство представляло полную, а главное, надежную информацию о количестве и составе товарно-материальных ценностей в организации [3, с. 120]. Так же руководителю предприятия необходимо принять решение о том, по какой оценке будут списываться материально-производственные запасы. Например, в случае если организация занимается оказанием услуг по ремонту, в котором так же используются запасные части для ремонта, целесообразнее применять метод ФИФО (акроним англ. First In, First Out - первым пришёл - первым ушёл). Данный метод считается более точным по сравнению с методом средней себестоимости. Средняя себестоимость удобна для списания канцтоваров, хозтоваров и других материалов в коммерческих организациях, которые не хотят видеть скачки в ежемесячных затратах, которым необходимы наиболее стабильные показатели из месяца в месяц.

Принятие решений относительно управления материалами компании влияет на все этапы экономической деятельности субъекта хозяйствования. В этой связи на современном этапе для любой организации важнейшей функцией является анализ эффективности управления запасами.

Первостепенной задачей является установление критериев признания политики управления запасами в экономическом субъекте эффективной. К ним можно отнести:

- контроль оборачиваемости запасов, обеспечение необходимого уровня скорости оборачиваемости, мониторинг отраслевых показателей оборачиваемости запасов;

- контроль выполнения бюджетов, выявление причин отклонений фактических показателей, связанных с запасами, от плановых, нормативных;

- анализ динамики материалоемкости продукции, рентабельности использования запасов на предприятии [4, с. 173];

- контроль движения запасов, рациональные закупки и использование, чтобы не допустить как переизбыток, так и нехватку запасов в местах их 


\section{ВСЕРОССИЙСКИЕ НАУЧНЫЕ ЧТЕНИЯ

хранения для целей производства, управления и других подразделений.

Одним из важнейших показателей, на который должно быть акцентировано внимание, является показатель оборачиваемости материальнопроизводственных запасов. Данный показатель рассчитывается либо в виде относительного показателя в форме коэффициента, либо в виде временного показателя (дни или иной измеритель), отражающего длительность оборота конкретного вида или группы запасов.

С позиции изучения состояния запасов в рамках оценки эффективности политики управления ими анализируются себестоимость запасов, транспортнозаготовительные затраты, количество запасов в местах их хранения.

При анализе себестоимости запасов, хранящихся на складе, особое значение имеет выполнение требований ФСБУ 5/01 в части контроля обесценения запасов (в случае превышения фактической себестоимости над чистой продажной стоимостью). Причиной обесценения запасов может быть как их длительное хранение, в течение которого инфляция значительно изменила рыночную стоимость единицы запасов, а также моральное устаревание, связанное с развитием науки, техники и технологий.

В случае выявления фактов обесценения запасов нормативные документы требуют от экономических субъектов (кроме тех, кто не относится к субъектам, имеющим право на применение упрощенных методов бухгалтерского учета) создавать резерв на сумму превышения фактической себестоимости над чистой стоимостью продажи.

С точки зрения оценки эффективности управления запасов целесообразно анализировать динамику резерва под обесценение материальнопроизводственных запасов, а также выявлять причины возникновения обесценения.

Рациональная система ведения учета материально-производственных запасов в деятельности торговой организации должна обеспечивать благоприятные условия для хозяйствующего субъекта. Работники торгового предприятия должны заключать договоры на поступление и продажу товарных запасов с наименьшими рисками застоя товара, то есть уменьшать или увеличивать суммы ежемесячных оборотов по закупке и продаже товара в зависимости от сезона или региона пребывания. Должны ежемесячно анализировать остатки запасов и неликвидный остаток и контролировать его убывание [5, с. 140]. 
Руководству предприятия необходимо обеспечить сотрудников достойным оборудованием и программой для подробного отслеживания сроков поступления и выбытия товарных запасов. Также необходима мотивация сотрудников, для того чтобы данные сроки были сокращены к минимуму. Предприятию необходимо свести обязательства по отношению к контрагентам до минимума, а свои требования к ним доводить до максимума.

\section{Список литературы}

1. Татаровская Т.Е., Татаровский Ю.А. Финансовая устойчивость и деловая активность в анализе экономической безопасности предприятия // Российский экономический интернет-журнал. 2019. № 4. С. 128.

2. Джаферова С.Е., Сныткина А.А. Особенности управления товарными запасами в организациях торговли // Таврический научный обозреватель. №5 (декабрь). 2015. С. 45-48.

3. Яцук А.Л. Анализ проблем ведения бухгалтерского учета товаров предприятий оптовой торговли // Научный альманах. - 2018. - №5-1 (43). C. 118-121.

4. Бычкова С.М., Бадмаева Д.Г. Особенности учета и анализа материально-производственных запасов//Известия Санкт-Петербургского государственного аграрного университета. -2015. -№ 38. -С. 170-174.

5. Клычова Г.С., Закирова А.Р., Хусаинова А.С., Дятлова А.Ф., Никитенко И.Г. Развитие методического инструментария внутреннего контроля движения запасов // Вестник Казанского государственного аграрного университета. 2021. Т. 16. № 3 (63). С. 135-141.

(C) А.А. Меликян, Ю.А. Татаровский, 2021 